\title{
Status and determinants of other gainful activities by farmers in mountainous rural regions of Gilgit-Baltistan, Pakistan
}

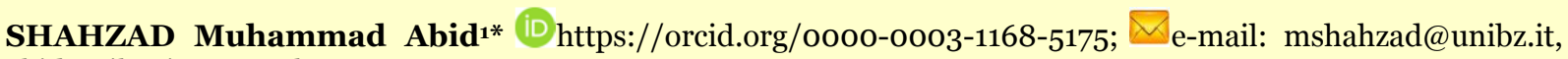 \\ abidagribusiness@yahoo.com
}

\author{
AHMED Vaqar² iDhtp://orcid.org/oooo-0002-3590-3504; e-mail: vaqar@sdpi.org \\ FISCHER Christian1 iD http://orcid.org/oooo-0002-5016-3962; e-mail: christian.fischer@unibz.it \\ ${ }^{*}$ Corresponding author \\ 1 Faculty of Science and Technology, Free University of Bozen-Bolzano, Bolzano 3910o, Italy \\ 2 Sustainable Development Policy Institute, Islamabad 44ooo, Pakistan
}

\begin{abstract}
Citation: Shahzad MA, Ahmed V, Fischer C (2021) Status and determinants of other gainful activities by farmers in mountainous rural regions of Gilgit-Baltistan, Pakistan. Journal of Mountain Science 18(10).
\end{abstract} https://doi.org/10.1007/s11629-021-6673-y

(C) The Author(s) 2021.

\begin{abstract}
Non-farm income sources are important for livelihood sustenance, especially in the mountainous regions of developing countries. To implement effective policies to improve economic development, policymakers need insights at the grassroots level. Yet, there is a lack of empirical evidence in the context of Pakistan. This study examines the current situation and the factors influencing the decision by farmers to engage in other gainful activities (OGAs) such as farm diversification and off-farm work in the northern mountainous regions of Pakistan. The study is based on quantitative survey data obtained from 459 farm managers and qualitative data from 24 key informants from five different districts in GilgitBaltistan. Utilizing a logistic regression model, a statistical analysis is conducted on farmer and farm characteristics to investigate the probability of farm managers to engage in OGAs. The survey results show that around $71 \%$ of farm managers are engaged in OGAs (with $24 \%$ in farm diversification, $61 \%$ in offfarm work and $15 \%$ in both). The share of female farm managers is $51 \%$ in farm diversification while male farm managers dominate off-farm activities (69\%). The most prevalent types of farm diversification are
\end{abstract}

Received: 11-Jan-2021

Revised: 07-Jun-2021

Accepted: 03-Aug-2021 the processing of farm products and tourism-related farm work, while the main off-farm activities are setting up grocery stores outside the farm, having salaried jobs or engaging in other non-agricultural business. There are significant differences between farmers with and without OGAs particularly regarding farmer characteristics, agricultural income and some other variables. The logit model results show that farmer characteristics mainly determine off-farm work activities while farm (and other) characteristics mostly explain farm diversification. These findings suggest that OGAs primarily exist as livelihood strategies. Farm diversification is linked with the long-term sustenance of agricultural activities while off-farm work is predominantly driven by economic needs. Both types of OGAs require specific support policies while attention needs to be given not to threaten regional food supply.

Keywords: Other gainful activities; Off-farm work; Farm diversification; Gilgit-Baltistan; Pakistan

\section{Introduction}

Rural areas are vital in many countries because these territories provide living spaces and natural 
resources for people despite the fact that now more than half of the world's population lives in and around cities (United Nations 2018). In particular, western rural area paradigms have changed during the last decades. Traditionally, the countryside has been seen from the perspective of economic sectors. Agriculture used to be the most important rural sector with a focus on the production of agricultural commodities both food and non-food (e.g., cotton). Starting with the Rio Earth Summit in 1992, the term "multifunctionality of agriculture" emerged which for instance has subsequently been integrated into the Common Agricultural Policy of the European Union (Fischer 2019).

The multi-functionality concept expresses the idea that agriculture not only produces physical commodities but also supplies non-commodity outputs or services such as landscape beauty, environmental externalities, or social and cultural benefits (e.g., preserving customs and traditions) (OECD 2009). By providing such services to rural communities, farmers can access additional income sources through farm diversification activities. At the same time, a growing world population and decreasing average farm sizes in developing countries (Lowder et al. 2016) force traditional farmers to supplement earnings from agricultural production by additional incomes from off-farm work.

Today, about 245 million people from developing and transition countries living in mountainous areas are particularly affected by constraints such as subsistence farming, environmental and climatic limitations, higher costs of production, lack of infrastructure and market access (Puri 2009; Rasul 2010; Rasul and Hussain 2015). Consequently, in particular for mountain farmers, it has become necessary, on the one hand, to continuously strive to sustain their production capacities and, on the other hand, engage in additional economic avenues such as diversification and taking up multiple jobs (Weiß et al. 2016). The rapidly changing circumstances encourage farmers to reallocate, adjust and reorganize their agricultural production modes and move towards offfarm sources to supplement household income. This process of restructuring is especially severe in the mountainous farming regions which are particularly vulnerable to socio-economic and environmental transformations (López-i-Gelats et al. 2011). These communities opt for 'livelihood diversification', i.e., the use of farm and off-farm resources to diversify income channels to sustain their livelihoods (Kassie et al. 2017).

The dynamics of farmers shifting from the farm to the non-farm economy have different implications in developing countries (Haggblade et al. 2007). Abandoning farms and greater involvement in the offfarm economy also carries concerns related to food insecurity especially in the agricultural regions of the Himalayan mountains (Hussain et al. 2016; Sati 2005). Nevertheless, in developing countries, agriculture is still cited as one of the most important contributors to rural livelihood (Awokuse and Xie 2015), including the Gilgit-Baltistan (GB) region, the northern mountainous province of Pakistan (Rasul 2010).

Farm diversification is defined as the development of income-earning activities, essentially using the resources of the farm, different from the conventional crop and livestock production activities associated with agriculture (Dries et al. 2011). On the other hand, gaining income from farm work along with other economic activities not utilizing the resources of the farm, carried out for remuneration is generally referred to as "off-farm work" (Tocco et al. 2016). The scientific literature describes the strategy to supplement the income base of farms through various types of on-farm and off-farm work also as 'other gainful activities' ('OGAs'), 'pluriactivity' or 'part-time farming', with some differences in definitions (Iqbal et al. 2015; Lakner et al. 2018; McNally 2002; Naudiyal et al. 2019; Su et al. 2016; Tocco et al. 2016). Fuller (1990) conceptualizes both on-farm and off-farm work of farmers as 'multiple job holdings'. There is a contentious debate on differentiating farm diversification from pluriactivity (Gasson and Ruth 1986, Lund 1991, Lopez-i-Gelats et al. 2015). However, for this paper, we use the concept of OGAs to be more inclusive of various types of onfarm and off-farm work other than the main farming activity for income generation purposes. OGAs are defined (following the European Commission 2008) as every activity other than traditional farm work, carried out for remuneration. This includes nonagricultural gainful activities performed on the holding itself (i.e., farm diversification activities such as the processing of farm products, selling accommodation to tourists, etc.) or on another agricultural holding, as well as non-agricultural activities.

Regardless of definitional complexities, the 
presence of OGAs indicates an intermediate stage of the rural shift towards a non-farm economy where farmers show discontent with farm productivity or farm income while they haven't yet completely moved towards non-agricultural industries (Liu et al. 2013). It has also been considered as a 'survival strategy' (Zabawa 1987), a gradual farm exit (Pietola et al. 2003), and as well as a long-term stable alternative (Kimhi 2000). The rationale for OGAs may vary depending on the context and population under consideration. Nevertheless, pluriactivity is widely linked with environmental sustainability, rural development, and food security measures particularly in developing countries, thus attracting substantial attention (Chase 2010; da Silva et al. 2015; McNally 2002).

Previous studies have empirically investigated OGAs (e.g., Barbieri and Mahoney 2009; Bateman and Ray 1994; Damianos and Skuras 1996; McNally 2001). In particular, the impact of OGAs on economic development and rural livelihood has been analyzed. The findings indicate that farm diversification and off-farm work are conducive to increasing farm production efficiency as well as labor and capital resource use, thus improving the financial situation of rural communities (Atamanov and Van Den Berg 2012; Barnes et al. 2014; Freyens and Mann, 2016; Vik and McElwee 2011). In the past, many proponents of OGAs have stressed its stabilizing effects on the agricultural economy in many industrial countries during structural change (Holland and Carvalho 1985; Pfeffer 1989; Robson et al. 1987; Rockström et al. 2017). Other researchers have stressed that the pursuit of income from OGAs is a risk management technique (Andersson et al. 2003; Jim Kinsella et al. 2000).

However, off-farm work has also been associated with a decreased presence of farmers on the farm, which can result in lower productivity (Kinsella et al. 2000; Zhang et al. 2008) and potential neglect of crops and/or farm animals (Darnhofer 2010). Farmers' choice to reduce risks and find stable income also contributes to farm exits. This could be regarded as positive in terms of its benefits in lowering stress on natural resources (such as water, soil, ecosystem, etc.) but can also have negative impacts on agricultural production and food security especially in the context of mountain farming in developing countries (Stellmes et al. 2013). Whether it is the lack of proper access to marketing channels or environmental production constraints, farmers are increasingly abandoning agriculture either wholly or partially (Atamanov and Van Den Berg 2012). As a result, many studies pointed to the increased off-farm work and farm abandonments and call for policymakers to determine sustainable levels of OGAs (Rosa et al. 2008; Vik and McElwee 2011; Iqbal et al. 2015).

Previous studies also analyzed the factors that influence the choice of diversification and off-farm work, such as farm and farmer characteristics, i.e., farmer age, education, experience and gender, farm size, and family conditions, etc. (Hansson et al. 2013; Maye et al. 2009; McNamara and Weiss 2005). Other studies considered variables such as household and spouse characteristics (Dries et al. 2011; Schmitt 2009). Moreover, the education of the farm household's labor force is especially linked with the likelihood of farmers' engagement in OGAs (Brosig et al. 2009). Other elements such as farmers' intrinsic and acquired abilities and skills, as well as knowledge and the motivation to innovate and diversify also affect the pursuit of OGAs (Niemelä and Häkkinen 2014).

Farmer characteristics constitute the basis for the formation of social capital which acts as a hidden resource in being productive and successful both in the agricultural and non-agricultural aspects of rural livelihoods (Ali et al. 2017). For instance, gender, age, marital status, etc. contribute to increased trust, bonding and respect in the local society and culture of the region. The literature broadly considers farmer characteristics as structural and relational components of social capital (Monge et al. 2008). However, because the literature focusing on the accumulation of social capital and its different components at the individual farmer level is limited (Phongsavan et al. 2006; Monge et al. 2008; GómezLimón et al. 2014), it is worthwhile studying farmer characteristics through this perspective. In particular in remote and marginalized mountain areas, where inter-personal contacts are limited, farmer characteristics and personal qualities have been found to be especially important for being able to engage in off-farm work activities (Fang et al. 2014).

Farm characteristics are another crucial factor affecting the possibility of OGAs in particular in mountain areas. Farm size is one of the most important farm characteristics, for instance, measured as the number of workers, land size, 
livestock unit numbers, etc. In a study in Austria, McNamara and Weiss (2005) used panel data from 39,621 farm households to find out that factors such as a large farm size are linked to diversification while larger family sizes and younger farmers are linked to off-farm work. Farm size can have different implications. First, larger farms can limit the possibility of pursuing an off-farm job because it demands the greater presence of farmers. Second, it can offer flexibility to set up diversification activities (Salvioni et al. 2020). Farms in the US have been found to be pursuing the off-farm route during financial stress (Paudel and Wang 2002).

Various other farm characteristics have also been associated with OGAs. Farm location is one such determinant, as proximity to urban centers can offer more off-farm opportunities (Paudel and Wang 2002). For instance, farm households living around urbanized localities are inclined towards off-farm employment, and the cost of commuting also can affect the decision to leave the farm (Guttman and Haruvi 1986; Kimhi 2010). The distance to nearby markets and access to the main road affects farmers' ability to market their products, thus favoring onfarm sales (Ilbery and Bowler 1993; Meert et al. 2005; Vandermeulen et al. 2006). Another element related to the location of the farm is the natural beauty and landscape value. Where a farm's nearness to a touristic area can enhance its potential for diversification and off-farm work, some geographical features such as altitude and topography of the farm can also pose constraints (Dries et al. 2011; Liu et al. 2013). Studies suggest that in less-favored areas there is less opportunity for conventional diversification (e.g., processing of farm products) but more "servicerelated diversification" (e.g., farm accommodation, agritourism, etc.) at places near touristic spots or naturally attractive areas (Sharpley and Vass 2006).

Finally, farm-external factors such as government policies and subsidies also affect the direction of agricultural migration. Studies found that government payments decreased operators' involvement in off-farm employment, essentially slowing down the rate of farm exit (Mishra et al. 2014; Serra et al. 2005).

In the view of this literature regarding determinants of OGAs, the following two research hypotheses are formulated, taking into consideration the context of the study area:

Farmer characteristics, which constitute the basis for farmers' social capital, are particularly important determinants affecting the likelihood of engaging in OGAs (farm diversification as well as off-farm work) especially in the mountainous areas such as GB (H1)

Farm characteristics such as size and location as well as farm-external variables also affect the likelihood of engaging in OGAs. However, the importance of individual variables may differ for farm diversification or off-farm work (H2)

Hence, the main objective of this study is to identify the factors underlying the decisions to start and sustain OGAs outside traditional agriculture by investigating how in particular different farmer and farm characteristics affect this decision. In addition, we present some qualitative group discussion responses to better understand farmers' say on the decision to pursue these activities. This understanding is key to evaluate the on-ground situation in GB from which we derive specific policy recommendations.

\section{Data and Methods}

\subsection{Data}

\subsubsection{Study area}

The region of GB has a total area of 72,496 km² with an estimated population of 1.8 million. It lies at the extreme north of Pakistan with a latitude of $35.8026^{\circ} \mathrm{N}$ and longitude of $74.9832^{\circ} \mathrm{E}$, neighboring the Xinjiang province of China in the north, Azad Kashmir to the south, the province of Khyber Pakhtunkhwa to the west, Afghanistan to the north, and India-administered Ladakh and Kashmir in the east. Most of the area (90\%) is mountainous, $4.0 \%$ is under forest and $4.2 \%$ is cultivable wasteland (IFAD 2015). More than half of GB is located above 4,500 meters from sea level. GB is administratively divided into ten districts - Astore, Diamer, Ghanche, Ghizer, Gilgit, Hunza, Nagar, Shighar, Kharmang and Skardu - with the regional capital being Gilgit city.

The GB region has the potential to become a business hub between Pakistan and China amidst the recent China Pakistan Economic Corridor initiative. The Gilgit-Baltistan Empowerment and SelfGovernance Order (2009) provided the local people with the right to their own legislature and political framework. Along with its substantial geopolitical 
importance, this region is heterogeneous as to its elevation, climatic features and topography. It carries a large potential in the production of horticultural crops, nuts, seeds and medicinal plants (Rasul and Hussain 2015). Like in other mountainous regions in developing countries, people in GB depend on subsistence farming, livestock, forestry, and some offfarm activities (Israr and Khan 2010). Despite the great potential in its agriculture, there is an increased disinterest in continuing traditional farming especially among the young rural population (Dinar et al. 2015).

During the last decades, the GB region has undergone a major transformation from a remotely located mountain agricultural region to a more literate rural society with an evolving urbanized look. Between 2006 and 2016, GB has experienced a notable decline in agricultural land use especially around the regions adjacent to the Karakoram highway (Anwar et al. 2019). Moreover, there is evidence of changes particularly in livelihood diversification and the structure of agricultural systems. Such changes are perceived as negative by older farmers as it reduces the self-sufficiency of households in terms of food production (Spies 2018).

Additionally, the region has recently experienced an increased inflow of tourists thus providing local farmers with opportunities in agri-tourism (Asif et al. 2017; Imran et al. 2014). These changes have caused a considerable shift from subsistence farming to more commercialized agriculture with a predominant nonfarm sector. The government of Pakistan, through its policy instruments, endorses diversification activities and aims at increasing rural income through agribusiness development. However, these instruments fail to promote off-farm activities.

Currently, the cropped area is only about $1.2 \%$ of the total area (IFAD 2015). GB has a particularly favorable climate for the production of horticultural crops, particularly apricots, cherries and tree nuts while cereal grains are produced mostly for domestic consumption (Khan et al. 2013). Its economy largely depends on dry fruits produced in small fractions of land scattered all over the region. The large potential in its horticultural cash crops has not yet been fully tapped. GB is primarily a rural society dotted with small urban centers where agriculture is still the primary occupation of rural people (IFAD 2015). Subsistence farming, outmigration and the diversification of household income channels is the way of life and livelihood strategy of most people in the Hindu Kush Himalayan region (Bhasin 2011; Hoermann and Kollmair 2009).

\subsubsection{Site selection and sampling}

This study covers five districts from the GB region - Astore, Ghizer, Gilgit, Hunza and Nagar. The choice of districts was made based on adequate environmental variability, agricultural importance and the diverse socio-economic profile of the area. The localities in the districts were selected based on the (a) reported high number of farmers and farming activity, (b) variable altitude within the district, and (c) different proximities to urban centers. For this study, rural localities were shortlisted first and then four to five main tehsils and villages representing most of the agricultural population of the area were chosen randomly. The following tehsils and villages were selected for surveying from each district (as shown in Fig. 1):

1) Gilgit: Danyore, Jalalabad, Minawar, Oshikhandass and Bagrote

Gilgit, being the capital city of GB, is the main destination for non-farm opportunities (such as trade, transportation, housing and construction, mineral resources and communication, etc.). However, agriculture is still the dominant sector in peri-urban and rural areas of the district, mainly producing cereal crops and some horticultural crops in the higher areas. Gilgit lacks significant rainfall, as the monsoon breaks against the southern range of the Himalayas. Irrigation for crops is obtained from rivers and melting snow water from higher altitudes. It is also a starting point for touristic activities in GB.

2) Ghizer: Gahkuch, Chatorkhand, Phander and Bubur

Ghizer is the westernmost district of GB, comprising several isolated valleys located at varying altitudes with a multi-ethnic population at a comparatively greater distance from main urban centers. The district is particularly susceptible to landslides. The diverse climatic conditions in Ghizer are highly favorable for the production of deciduous fruits and vegetables. The main crops are fruits, such as apples, pears, peaches, apricots, almonds, cherries, walnuts, some vegetables, and cereal crops, etc.

3) Hunza: Aliabad, Karimabad, Altit, Ganish and Askurdas

Hunza is one of the most touristic districts in GB. It is home to three major peaks (SistaghilSar, 


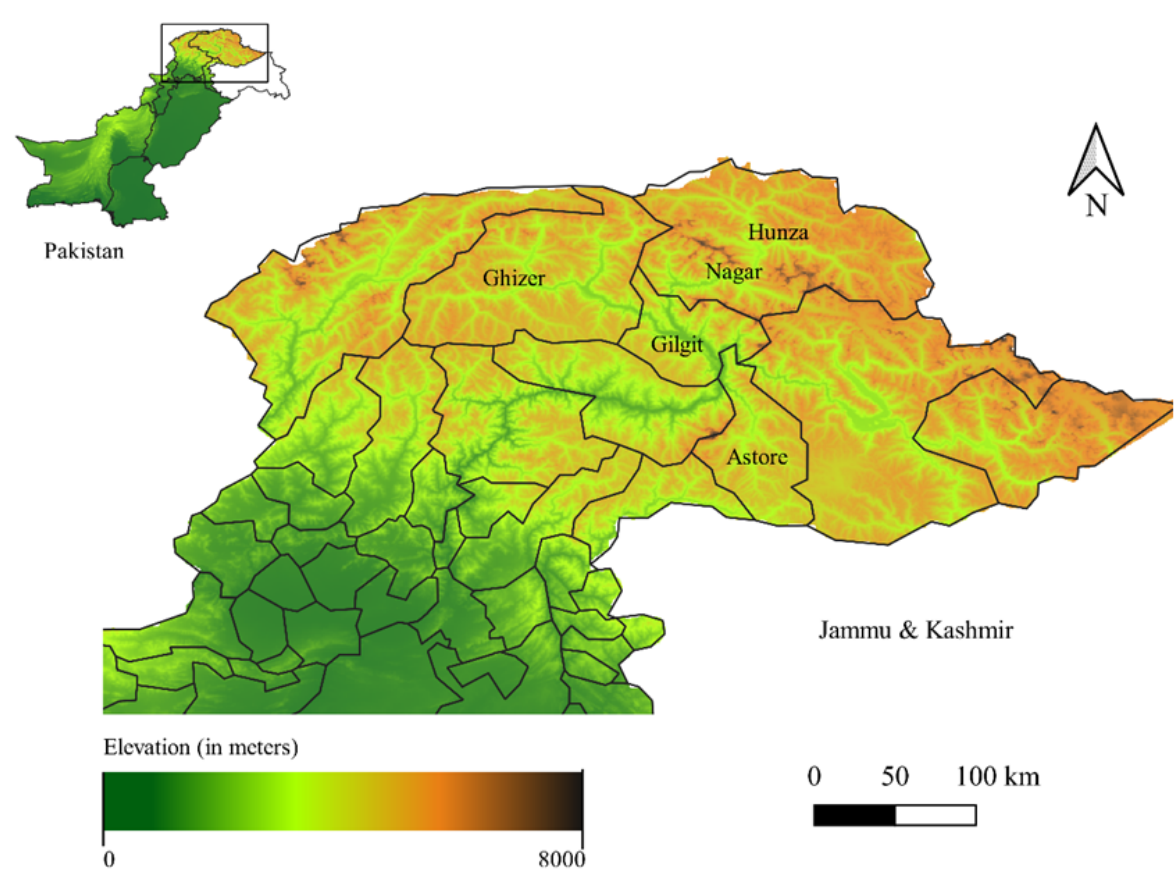

Fig. 1 Study area location in Gilgit-Baltistan (GB), Pakistan, and the altitudinal profile of the region. The districts selected for surveying have been highlighted with names.

BaturaSar and PassuSar). The altitude in the district ranges between 1391 and $7850 \mathrm{~m}$ (Qureshi et al. 2017). It is also prone to greater risks of natural disasters. According to surveyed farmers, Hunza reports greater effects of climate change resulting in longer summers and running streams even in winter. Major crops include wheat, potatos, vegetables, maize, barley, millet, etc., while cherries, grapes, apricots, apples, walnuts and almonds are the major fruits. The Hunza district is especially marked with community-based reciprocity and cooperation (Stadelbauer 2020).

\section{4) Nagar: Nagar I and Nagar II}

The Nagar district lies in a semi-arid mountain valley neighboring Hunza valley. Several high peaks of $>$ 7,000 $\mathrm{m}$ (such as Rakaposhi, Diran peak, etc.) are located in the surroundings of Nagar Valley which are popular among trekkers and mountaineering communities. Nagar has combined irrigated crop farming system with livestock that makes use of high pastures during the summer months. The main field crops are wheat, potatoes, maize, alfalfa, and buckwheat. Apricots, cherries and apples are the main horticultural crops. However, reliance on traditional agriculture is decreasing and farmers are shifting to high-value crops (Spies 2018).

5) Astore: Astore and Eidgah

The Astore district has the potential for ecotourism owing to its plant biodiversity and forests (such as the Rama forest). This region marks the highest rainfall. The local forests are also a source of subsistence timber, grazing and nontimber wood products.

A mix of stratified and random sampling methods was used. The farm households were selected randomly from the list of farmers in each village provided by the local agriculture research department. The list of farmers was kept up to date with the help of local heads. Within each village, $15 \%$ of the households were surveyed, using a random sampling technique. The survey team was accompanied and assisted by local research assistants assigned by the department of agricultural research of GB. To interview women farmers, the interviewing team consisted of women research assistants. This made the interviewing process more efficient and resulted in a high response rate. In case of the unavailability of the farm manager at the household, the next alternative household was chosen for the interview while making sure that the respondents are the main farm manager or the main decision-maker of the farm. The overall final response rate was $93 \%$.

\subsection{Survey methods and questionnaire}

As the first step to gather descriptive information regarding farmer decisions, underlying motives and a better understanding of local issues, key informant interviews were conducted. A key informant interview is an efficient technique to derive information from the target population. This method is especially useful when the primary purpose of the study is to generate suggestions and recommendations, information regarding attitudes and motives is required and quantitative data collected through other methods need interpretation (Kumar 1989).

Key informant interviews: A total of 24 farmer 
representatives including heads of the local support organization, village headmen (locally called numberdar) and sub-headmen (locally called moutaber) and some informed and educated farmers from all study areas were chosen as the key informants. The qualitative discussions were conducted in small groups where on some occasions local farmers also attended the sessions voluntarily.

Questionnaire survey: The other method of data collection used in the study was the farm household survey. Household surveying is an appropriate and commonly used method to gather demographic data (Sano et al. 2015). A single household is often comprised of more than one family sharing a single kitchen, as a cultural norm of 'joint family system' in Pakistan. In such a case, the farm household was considered as a single unit. The unit of the analysis is the farm manager, the main caretaker and decisionmaker at the farm, and we are interested in his/her pursuit of OGAs.

The study is primarily based on data collected through a questionnaire from 459 farm managers from different districts of GB. The questionnaire was pre-tested and administered to obtain information on various topics such as the demographic profile of the area, livelihood strategies, motives and rationale for OGAs. The questionnaire consisted of a mix of openended and close-ended (including nominal and Likert scale) questions. The questionnaire content mainly covered farm and farmer characteristics, information regarding family and livelihood, farmers' community characteristics, variables affecting the availability of off-farm jobs and farmers' opinion on OGAs.

\subsection{Statistical analysis}

In this study, both qualitative and quantitative methods are used to analyze research questions. We provide an initial descriptive analysis concerning the current situation of OGAs followed by the representative responses obtained from key informant interviews to express the opinions of farming communities. The qualitative information is used to understand the underlying rationale for engaging with the off-farm economy.

A logit model was employed to analyze the factors affecting the choice of different types of OGAs. This is because the indicator of farm diversification and offfarm work - whether the farm manager is involved in either activity - is a dichotomous variable rather than a continuous variable. The explanatory variables used in the study to explain farmers' choice of OGAs include farmer characteristics, farm size, farm location, farm income and other factors that may influence the choice of involvement in farm diversification or off-farm work. To deepen our understanding, we combined two strands of scientific literature by distinguishing sub-groups of OGAs, i.e., farm diversification and off-farm work to elicit a complete picture of the current state of OGAs in GB. Our study provides the marginal effects of each independent variable to quantify the effect sizes on the dependent variables.

\section{Results}

\subsection{Current state of OGAs}

As identified by the responses received, we categorized farm managers or decision-makers into two classes. First, those who are pursuing farming as their main and only occupation are 'farmers without OGAs'. Second, those who supplement their household income through OGAs by either setting up diversification activities on the farm or taking up a non-farm job or both, are termed, 'farmers with OGAs'. Out of the total of 459 interviewed farm managers, 328 (71\%) are involved in OGAs. Out of the total number of farm managers with OGAs, $24 \%$ have only on-farm diversification activity, $61 \%$ are only involved in off-farm jobs while $15 \%$ have both. The detailed summary statistics are presented in Table 1.

1) The basic situation of farmers with OGAs

The total sample constitutes $65 \%$ male-headed farms and 35\% female-headed farms. The labor force with off-farm work is also dominated by men, constituting 213 male and 94 female farm managers. On the contrary, the share of women in diversification activities is larger than in off-farm work (51\%).

The farm managers with off-farm work are mainly within the 31-45 year age category, while most farm managers involved in diversification are older than 45 years.

The average number of years of education attained by farm managers with off-farm work and diversification is 9.2 and 9.1, respectively, which is slightly more than that of farm managers without OGAs (8.2). The farm managers working off-farm who have schooling levels as illiterate, up to 6 years, 8 
Table 1 Details of variables used in the regression models

\begin{tabular}{|c|c|c|c|c|}
\hline Variables & & Description & Mean & $\begin{array}{l}\text { Standard } \\
\text { deviation }\end{array}$ \\
\hline \multirow{2}{*}{$\begin{array}{l}\text { Dependent } \\
\text { variables }\end{array}$} & $\begin{array}{l}\text { Farm } \\
\text { diversification }\end{array}$ & $\begin{array}{l}=1 \text { if farmer is involved in farm diversification, } o \\
\text { otherwise }\end{array}$ & 0.29 & 0.45 \\
\hline & Off-farm work & $=1$ if farmer is involved in off-farm work, $\mathrm{o}$ otherwise & 0.67 & 0.47 \\
\hline \multirow{10}{*}{$\begin{array}{l}\text { Farmer } \\
\text { characteristics }\end{array}$} & Gender & $=1$ if farmer is male, 0 otherwise & 0.65 & 0.48 \\
\hline & Age & $\begin{array}{l}=0 \text { if age is }<18,=1 \text { if } 18-30,=2 \text { if } 31-45 \\
=3 \text { if } 46-55,=4 \text { if } 56-64 \text { and }=5 \text { if } 65 \text { and above }\end{array}$ & 2.54 & 1.41 \\
\hline & Education & $\begin{array}{l}=0 \text { if the farmer is illiterate, }=1 \text { if has schooling up to } 6 \\
\text { years, }=2 \text { if } 8 \text { years, }=3 \text { if } 10 \text { years, }=4 \text { if } 12 \text { years and }=5 \text { if } \\
\text { university graduated or more }\end{array}$ & 2.59 & 1.32 \\
\hline & Experience & $\begin{array}{l}=0 \text { if experience is }<5 \text { years, }=1 \text { if } 5-10,=2 \text { if } 11-15,=3 \text { if } \\
16-20 \text { and }=4 \text { if more than } 21\end{array}$ & 2.41 & 1.43 \\
\hline & Marital status & $=1$ if the farmer is married, 0 otherwise & 0.85 & 0.36 \\
\hline & $\begin{array}{l}\text { Number of children } \\
\text { (aged }<16 \text { years) }\end{array}$ & Number of kids aged less than 16 & 1.54 & 1.32 \\
\hline & Farm heir & $=1$ if farm has a declared farm heir, $\mathrm{o}$ otherwise & 0.80 & 0.40 \\
\hline & Spouse on farm & $=1$ if the farmer's spouse work on farm, $\mathrm{o}$ otherwise & 0.81 & 0.39 \\
\hline & Health status & $\begin{array}{l}=1 \text { if farmer rates his health as very good; } 2 \text { fairly good; } 3 \\
\text { average; } 4 \text { poor; } 5 \text { very poor }\end{array}$ & 1.73 & 1.12 \\
\hline & Trainings & $\begin{array}{l}=1 \text { if the farmer has attended an agricultural training, } o \\
\text { otherwise }\end{array}$ & 1.59 & 2.51 \\
\hline \multirow{7}{*}{ Farm size } & Land owned & Total land owned by the farmer in kanals & 12.73 & 22.31 \\
\hline & $\begin{array}{l}\text { Land under } \\
\text { cultivation }\end{array}$ & Total land under agricultural use in kanals & 6.89 & 6.41 \\
\hline & Livestock units & Total number of livestock units owned & 6.28 & 12.55 \\
\hline & Total workers & Total number of workers on the farm & 4.40 & 2.10 \\
\hline & Hired workers & Total number of hired workers on the farm & 1.00 & 1.96 \\
\hline & Family workers & Total number of family workers on the farms & 3.44 & 2.40 \\
\hline & $\begin{array}{l}\text { Total household } \\
\text { members }\end{array}$ & Total number of household members & 8.57 & 4.01 \\
\hline \multirow{3}{*}{ Farm income } & Agricultural income & $\begin{array}{l}\text { Total agricultural income in previous year in Pakistani } \\
\text { rupees (ooos) }\end{array}$ & 80.10 & 92.85 \\
\hline & $\begin{array}{l}\text { Farm income } \\
\text { satisfaction }\end{array}$ & $\begin{array}{l}=1 \text { if the farmer is satisfied with the farm income, } 0 \\
\text { otherwise }\end{array}$ & 0.24 & 0.43 \\
\hline & Subsidy & $=1$ if the farmer has received any subsidy, $\mathrm{o}$ otherwise & 0.27 & 0.44 \\
\hline \multirow{4}{*}{ Farm location } & Farm altitude & Altitude of the farm in meters & 2,400 & 580 \\
\hline & $\begin{array}{l}\text { Nearness to a } \\
\text { touristic spot }\end{array}$ & $=1$ if farm is located near a touristic location, 0 otherwise & 0.38 & 0.49 \\
\hline & $\begin{array}{l}\text { Distance from main } \\
\text { city }\end{array}$ & Distance between the farm and main city in kilometers & 15.92 & 15.15 \\
\hline & $\begin{array}{l}\text { Distance from main } \\
\text { road }\end{array}$ & Distance between the farm and main road in kilometers & 1.34 & 2.56 \\
\hline \multirow{4}{*}{ Others } & $\begin{array}{l}\text { Specialist } \\
\text { horticulture }\end{array}$ & $=1$ if farm specializes in horticulture, $\mathrm{O}$ otherwise & 0.41 & 0.49 \\
\hline & $\begin{array}{l}\text { Farm ownership } \\
\text { nature }\end{array}$ & $\begin{array}{l}=1 \text { if farm is organized as a sole proprietorship, } 0 \\
\text { otherwise }\end{array}$ & 0.81 & 0.39 \\
\hline & Changes on farm & $\begin{array}{l}=1 \text { if the farmer has made changes in farm production in } \\
\text { last } 5 \text { years, } o \text { otherwise }\end{array}$ & 0.53 & 0.50 \\
\hline & Farm evaluation & $\begin{array}{l}=1 \text { if farmer evaluates the development of his farm } \\
\text { during last } 24 \text { months as declined significantly; } 2 \\
\text { declined somewhat; } 3 \text { remained the same; } 4 \text { improved } \\
\text { somewhat; } 5 \text { improved significantly }\end{array}$ & 3.33 & 1.33 \\
\hline
\end{tabular}

years, 10 years, 12 years and university graduated account for $1 \%, 22 \%, 19 \%, 26 \%, 21 \%$ and $10 \%$, of the sample, respectively. The number of years of education decreases with the age of the farm manager. There are only a few illiterates or less-than-primary- school farm managers with off-farm work, perhaps due to fewer off-farm opportunities. There are more than $40 \%$ of farm managers with a diversification activity who attended school for less than 10 years.

Most of the farm managers, both with OGAs 
(84\%) and without OGAs (87\%), are married. Farm managers with off-farm work and diversification have on average 1.6 and 1.8 children (aged less than 16), respectively, while the average for farm managers without any OGA is 1.3 children. There is a slight difference between the total number of household members for farm managers with both types of OGAs and without OGAs, i.e., 8.6 and 8.1 versus 7.8. Around $70 \%$ of the total farm managers with off-farm work and $60 \%$ with farm diversification marked their physical health as 'very good'. Farm managers having a 'poor' and 'very poor' health status are slightly higher in the farm diversification category. Other characteristics, such as the number of trainings attended, are also different for both types of farm managers with and without OGAs. About $56 \%$ of farm managers involved in off-farm activity never attended any agricultural training, while the share is $38 \%$ for farmers with diversification activity.

The stated annual agricultural income in the previous year remained approximately 80,000 Pakistani Rupee (PKR) for the whole sample. There are significant differences between farm managers with and without OGAs. The previous year's agricultural income of farm managers with no OGAs remained slightly above 100,000 PKR, while the stated average farm income of farm managers with an off-farm job is around 70,000 PKR and with diversification activity is 84,000 PKR.

2) Farm characteristics of farmers with OGAs

Most of the farm managers (81\%) own the land they farm. Farmers without OGAs on average own more land (13.7 kanals) than their counterparts (12.3 kanals). Furthermore, the land under cultivation greatly differs between the two groups. The average number of kanals under cultivation for farm managers working off-farm is 6.2 while farm managers with diversification cultivated an average of 7 kanals of land. Farm managers with OGAs employed a slightly higher number of family workers and hired workers. The average number of family workers is roughly the same for both types of OGAs while there were more hired workers employed on farms with diversification. Poultry and livestock rearing coexist with arable crop production as a cultural norm in the region. However, the number of livestock units owned by farm managers with both types of OGAs is slightly higher. The average number of livestock units on farms with a manager working off-farm is 6.4 while with a diversification activity it is
7.1. On the other hand, farms without OGAs have on average 5.6 livestock units.

Farms in some districts have the possibility of growing high-value horticultural crops thus increasing farmer incomes especially from selling cherries, apricots, apples, almonds, or other nuts. These farms offer greater potential for setting up diversification activities. This is why around $50 \%$ of diversification in the sample occurs on farms specializing in horticulture.

3) Location-related characteristics of farm managers with OGAs

Farm managers are more likely to participate in OGAs when the farm is located near city centers or main towns where off-farm activities are more accessible. For farms with a manager with off-farm work, the average distance between the farm and the main city is 14.6 kilometers which is about 5 kilometers less than those farms operating without OGAs. The distance is even shorter (12.9 kilometers) for farms involved in diversification. Around $18 \%$ of the farm managers with OGAs have private jobs in a nearby city or town. The distance from the farm to the main road is slightly lower for farms without any OGAs than for their counterparts. In the mountains, if the farm is situated near a touristic location, the household has better chances of finding an off-farm opportunity. Around $32 \%$ of the total farms are located near a touristic spot, out of which $78 \%$ are operated by a farm manager with OGAs.

4) Stated intentions and perceptions of farm managers

Farm managers were asked to evaluate the development of their farm in the last 24 months and mark their progress from 'declined significantly' to 'improved significantly' on a scale of 1 to 5 . Noticeably, more than $50 \%$ of the farm managers with diversification activity believe that their farm has improved in the last 2 years. Of the farm managers with an off-farm activity, about $47 \%$ evaluated their farm's performance as improved during the last 24 months, $29 \%$ as declining, while almost $24 \%$ believe that it remained steady.

Most of the respondents are dissatisfied with their farm income. However, farm managers having off-farm income showed larger discontent with farm earnings. Of the total farm managers with OGAs, 80\% conveyed their dissatisfaction with farm income while in the case of farm managers without OGAs, the dissatisfaction drops by about 20\%. Respondents 
often show a biased response to the questions related to income or income satisfaction. Nevertheless, these statistics help to recognize the trends.

We asked the farm managers if there were any modifications made on the farm in the last 5 years, particularly changes in the production scale (addition or abandonment of land or a crop) or farm type. In response, $56 \%$ of the farmers with OGAs and $43 \%$ of farm managers without OGAs were affirmative of making changes on their farms. Of the total farm managers with OGAs, $38 \%$ reported to add/relocate more land for orchards and fruit farming, 18\% reduced land for cereal crops, $17 \%$ abandoned some part of agricultural land for various non-farm purposes, $15 \%$ added and invested unused land for forestry, $10 \%$ relocated land for vegetables, livestock and various diversification activities and $2 \%$ stated abandoning their farmland for construction. Similar trends are observed for farm managers without OGAs, except there is no stated land abandonment.

\section{5) Types of OGAs}

With increasing difficulties in sustaining livelihood, it is inevitable for some farm households, especially in developing countries, to diversify their income channels (Dedehouanou and McPeak 2020; Gautam and Andersen 2016). Therefore, farm households opt to set up farm diversification, find offfarm jobs or use a mix of these approaches to overcome economic hardships.

Farm diversification: Farm diversification is more liked by female than male farm managers. Of the total farm managers with OGAs, the share of women involved in farm diversification is slightly above $50 \%$. This is partly due to cultural hindrances and relatively fewer opportunities for women in the off-farm job market. Interventions by local NGOs such as the Aga Khan Rural Support Programme

Distribution of share by the type of off-farm activity

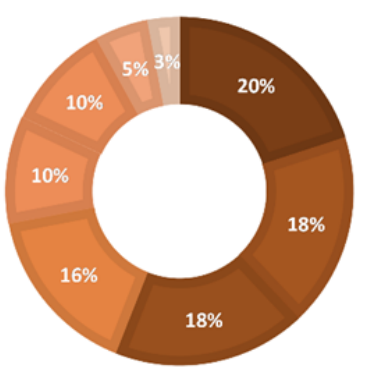

- Grocery shop/General store

- Private job

घ Other non-agricultural business

= Tourism related work

a Agricultural work on other farms

a Government job

= Services

m Other reoriented local subsistence agriculture toward highvalue cash crop production and helped setting up small-scale enterprises in the region that had a particularly lasting impact which resulted in the prevalence of farm diversification activities (AKRSP 2017; Benz 2016). However, in the northern mountainous regions of Pakistan, gender-specific roles in agriculture are prevalent. Many women choose their roles within households out of their personal preferences. Nevertheless, several progressive women (mostly in the districts Gilgit and Hunza) expressed their interest and involvement in off-farm work as well. Diversification is more dominant in the age group 31-45 (39\%), 46-55 (21\%) and 56 and above (23\%). While most younger farm managers do not prefer involvement in farm diversification.

When asked about the type of diversification activities, the processing of farm products is found as the most widely adopted activity, which is practiced on $29 \%$ of all farms as shown in Fig. 2. Most women set up a small processing plant on the farm and market their products directly to local buyers, tourists, or outside traders especially in the districts of Ghizer and Gilgit. Tourism-related diversification has especially been on the rise, as locals have reported selling farm-produced juices, wine, dry fruits and other specialties to local and foreign tourists. The districts Nagar and Hunza are particularly known for this type of diversification activity. Other important ones are forestry, setting up on-farm shops for fresh fruits and vegetables, tourism, handicrafts, woodcutting, renting out farm equipment and other activities such as beekeeping, livestock breeding, farm tours, 'do-your-own cherry-picking', etc. In addition to this, women are particularly involved in the handicrafts business.

Distribution of share by the type of diversification activity

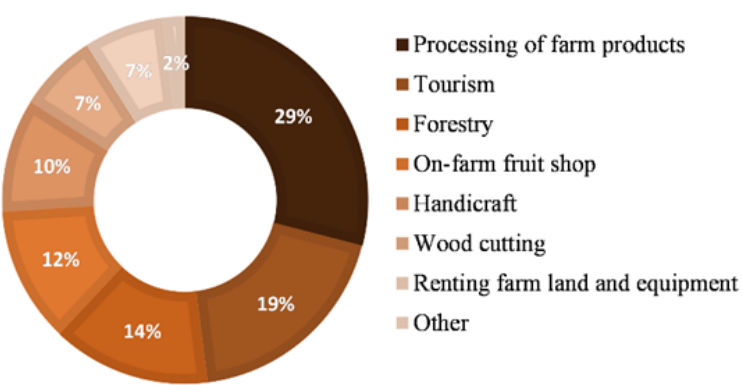

Fig.2 Contribution of different other gainful activities by categories. 
Off-farm work: To ensure higher and more stable incomes for instance to better cope with the seasonality of agricultural earnings, farmers look for off-farm jobs. The off-farm job sector is mainly occupied by males. Of the farm managers involved in off-farm jobs, $69 \%$ are men. Around $70 \%$ of the farm managers with off-farm work are between 18 and 45 years old. Sixteen percent of farm managers from the age group 45-55 years and $15 \%$ from the ' 56 and above' age group have an off-farm work. The proportion of retirees and older farmers is comparatively lower but nevertheless indicates the necessity and need for a supplementary income in the household.

As evident from Fig. 2, the most frequent offfarm activity that the farm managers have tried out is setting up a small general store selling groceries (20\%) to nearby residents in almost all regions of GB. The GB region holds a special status and is given exclusive tax exemption on certain food commodities which encourages people to start these business activities at a small-scale level. Eighteen percent of our sample farmers reported having a private job in the city center or nearby main town most of which are residing in the vicinities of the Gilgit district and the main town of Hunza. The tourism industry, especially in the recent past, has provided ample off-farm opportunities. Setting up boarding and lodging facilities, supplying porters for expeditions and trekkers and guided tours are such ventures where the local rural population earns their livelihoods.

\subsection{Issues affecting farmers}

Many factors influence the participation of households in OGAs. When asked to state their extent of agreement, on a scale of 1 to 7 from 'strongly disagree' to 'strongly agree', to a series of suggested problems, farm managers most commonly chose market-related issues. Individual scores are shown in Fig. 3. Production-related issues like post-harvest losses, unavailability of superior quality cultivars, and pathological problems are considered important.

When asked, "What is your opinion on supplementing household income from sources other than farming?", $53 \%$ of the respondents strongly agreed to 'it is crucial to afford a livelihood' (Fig. 4). The second most frequently marked (47\%) 'strongly agreed' category is on 'it reduces financial stress'. Generally, most farm managers agreed that bringing their land, capital and labor resource into efficient utilization is best. Out of 209 respondents, 38\% agreed and $33 \%$ strongly agreed that OGAs are the utilization of surplus resources and under-employed labor. A large share of respondents believe it to be essential supplementary support during winters, and financial means during summer. Around $19 \%$ of the responding farm managers strongly agree that OGAs are helping them stay in their forefather's business. Otherwise, their small farms on marginal land would have been abandoned a long time ago.

\subsection{Qualitative responses to the rationale for OGAs}

During key informant interviews, we asked "What do you think is the main motivation or reason for participation in OGAs?" Twenty-four out of 30 (80\%) respondents answered the question. The respondents mainly indicated unavailability of land, hindrances in commercial farming, climatic constraints, lower value of output, lack of institutional support and better income opportunities outside traditional agriculture as the main rationale for OGAs.

Smaller agricultural landholdings are one of the main causes of non-reliance on agricultural income. Farms in GB are mainly inherited through generational continuity which results in further fragmentation of farms. These farms primarily fulfill domestic consumption requirements. Which is why most small farms continue to survive and an exit from agricultural production does not occur on these farms. Like many others, 53 years old, Ashraf stated:

"Farming is our ancestral profession, and because of limited expertise and resources we have, we are bound to stay in this profession. Owing to its small size, our landholding merely satisfies our domestic consumption. I and my spouse look for agricultural and non-agricultural off-farm work to support other household expenses."

Many farmers have shifted or planned to shift towards high-value food cropping. However, due to post-harvest losses and the absence of an efficient marketing infrastructure, the profit margins are minimal, pushing farmers towards supplemental income from off-farm sources. Some respondents also added that proper branding, building processing plants in the region and curtailing post-harvest losses could resolve most of the marketing problems. These people look at farming as their future:

"Farming is our future. This land is suitable for 
fruit farming. I am keeping my farmland viable by expanding it through introducing new ventures on it. During the "cherry blossom" season, I with my family welcome tourists and offer accommodation and local cuisine." (Saqib Hussain, 60)

Participants especially from parts of Ghizer and Nagar II agree on the climatic factors to be responsible for susceptibilities in farm income. Farms located near high mountains and unfavorable locations offer less value in farming. Rural households largely depend on tourism, transport and other nonfarm businesses. The cultivated land is mostly used for domestic consumption or selling in the local market. Also, because the farmland is covered with snow for most of the year and is unusable for agriculture, farmers are thus bound to look for nonagricultural income. Iqbal Bano, who's a 38-year-old female farm manager expressed her views as:

"More than $80 \%$ of my landholding is not suitable for cultivation because of its nearness to the mountain. Most of the land is at high risk of land sliding. Land reforms under the projects like the ones of the International Fund for Agriculture Development (IFAD) can bring acres of land under cultivation. For now, I must find my major income in the tourism sector."

Another perspective involved the changing agricultural outlook of the region. The respondents stated that lower output from agriculture (either because of lower farmgate prices or lower yield) and higher returns from non-farm activities (such as tourism and transport) influence farmers to lower their dependence on farm earnings. Especially young farmers tend to choose off-farm work because of higher earnings. However, most farmers do not support exiting the farm business merely for higher monetary benefits associated with the non-farm economy but because of their ancestral values and social identity attached to it. Most respondents including some young farmers considered farming as their long-term occupation, as they perceive nonagricultural activities as a seasonal solution to a temporary lower income situation. Furthermore, farmers called for institutional support to incentivize farmers to continue farming through specialized subsidies:

"Direct government intervention is rare, at least in our town, Dain. In 2016, a government project supported potato growers and provided us with good-quality seed potatoes. After that, we did not get any subsidy. Lack of institutional support is what made us think of entering new non-agricultural ventures." (Moosa Wali, 54)

"Abandoning our ancestral land is a difficult decision to make, but the fact is, we are devoid of basic inputs. GB is emerging as an attractive tourist destination. I'm afraid that better income opportunities will shift most of the farmers towards hoteling and restaurant businesses." (Muhammad Ismail, Fida Hussain, 40)

\subsection{Factors affecting involvement in OGAs}

In Table 2 we include the two-way sample mean comparison $t$-test to compare the group of farmers with and without OGAs. The key difference appears to be in the farmer characteristics, specialization, size of farmland and agricultural income, etc.

The results suggest that farmers with better health conditions, lower age and more acquired skills are more likely to have off-farm work. The significant difference with respect to agricultural income

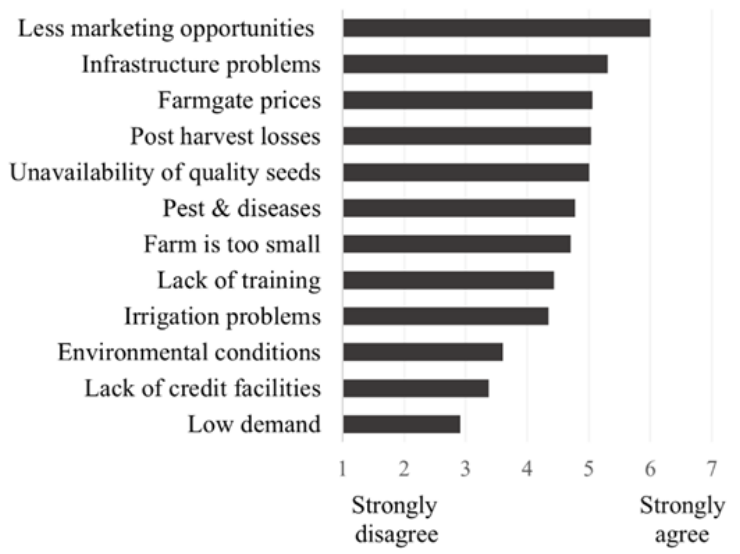

Figure 3 Distribution of scores by farmers for issues identified as factors pushing towards non-farm economy, from Likert scale questions. Respondents were farm managers in GB, Pakistan $(n=251)$.

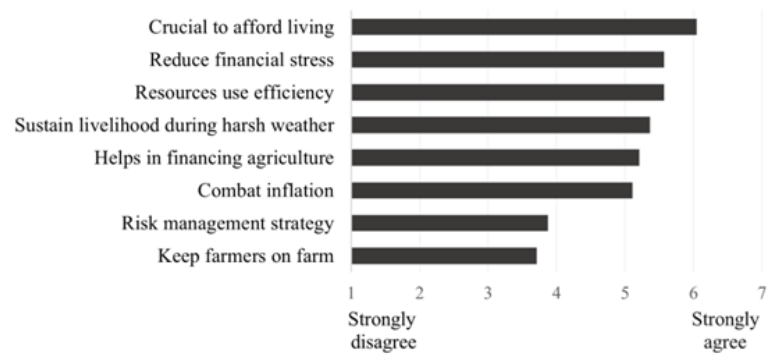

Figure 4 Distribution of scores by farmers marking their perception of OGAs, from Likert scale questions. Respondents were farm managers in GB, Pakistan ( $n=$ 300). 
Table 2 Two-way sample mean comparison $t$-test for other gainful activities (OGAs)

\begin{tabular}{|c|c|c|c|c|c|c|c|}
\hline \multirow[t]{2}{*}{ Variables } & & \multicolumn{3}{|c|}{$\begin{array}{l}\text { Involvement in farm } \\
\text { diversification }\end{array}$} & \multicolumn{3}{|c|}{ Involvement in off-farm work } \\
\hline & & Yes & No & Dif. & Yes & No & Dif. \\
\hline \multirow{10}{*}{$\begin{array}{l}\text { Farmer } \\
\text { characteristics }\end{array}$} & Gender & 0.61 & 0.67 & 0.06 & 0.69 & 0.56 & $-0.13^{* * *}$ \\
\hline & Age & 3.49 & 3.28 & $-0.21^{*}$ & 2.29 & 3.03 & $0.73^{* * *}$ \\
\hline & Education & 2.78 & 2.51 & -0.27 & 2.76 & 2.23 & $-0.53^{* * *}$ \\
\hline & Experience & 3.40 & 3.41 & 0.01 & 3.42 & $3 \cdot 39$ & -0.04 \\
\hline & Marital status & 0.92 & 0.82 & -0.10 & 0.84 & 0.88 & 0.04 \\
\hline & Number of children (aged $<16$ years) & 1.83 & 1.42 & $-0.41^{* * *}$ & 1.56 & 1.49 & -0.07 \\
\hline & Farm heir & 0.88 & 0.76 & $-0.12^{* * *}$ & 0.79 & 0.79 & -0.00 \\
\hline & Spouse on farm & 0.89 & 0.78 & $-0.11^{* * *}$ & 0.89 & 0.79 & $-0.10^{*}$ \\
\hline & Health status & 1.74 & 1.73 & -0.01 & 1.56 & 2.08 & $0.52^{* * *}$ \\
\hline & Trainings & 2.03 & 1.41 & $-0.63^{* *}$ & 1.43 & 1.93 & $0.50^{* *}$ \\
\hline \multirow{7}{*}{ Farm size } & Land owned & 13.23 & 12.52 & -0.71 & 11.66 & 14.90 & 3.25 \\
\hline & Land under cultivation & 7.07 & 6.82 & -0.26 & 6.17 & 8.35 & $2.18^{* * *}$ \\
\hline & Livestock units & 7.17 & 5.90 & -1.28 & 6.43 & $5 \cdot 97$ & -0.46 \\
\hline & Total workers & 4.70 & $4 \cdot 37$ & -0.33 & 4.43 & 4.54 & 0.11 \\
\hline & Hired workers & 1.46 & 0.81 & $-0.65^{* * *}$ & 0.93 & 1.15 & 0.22 \\
\hline & Family workers & $3 \cdot 32$ & 3.49 & 0.17 & $3 \cdot 38$ & 3.56 & 0.18 \\
\hline & Total household members & 8.36 & 8.66 & 0.29 & 8.62 & 8.47 & -0.15 \\
\hline \multirow{3}{*}{ Farm income } & Agricultural income & 84.40 & 78.30 & -6.09 & 66.17 & 108.21 & $42.03^{* * *}$ \\
\hline & Farm income satisfaction & 0.16 & 0.27 & $0.11^{* * *}$ & 0.21 & 0.30 & $0.10^{* *}$ \\
\hline & Subsidy & 0.40 & 0.22 & $-0.18^{* * *}$ & 0.28 & 0.27 & -0.01 \\
\hline \multirow{4}{*}{ Farm location } & Farm altitude & 2,348 & 2,343 & -5.00 & 2,316 & 2,403 & 87.00 \\
\hline & Nearness to a touristic spot & 0.49 & 0.34 & $-0.15^{*}$ & 0.40 & 0.37 & $-0.03^{*}$ \\
\hline & Distance from main city $(\mathrm{km})$ & 12.93 & 17.16 & $4.23^{* *}$ & 14.60 & 18.56 & $3.96^{* *}$ \\
\hline & Distance from main road $(\mathrm{km})$ & 1.49 & 1.28 & -0.21 & 1.46 & 1.10 & -0.36 \\
\hline \multirow{4}{*}{ Others } & Specialist horticulture & 0.50 & 0.38 & $-0.12^{* *}$ & 0.35 & 0.55 & $0.20^{*}$ \\
\hline & Farm ownership nature & 0.74 & 0.84 & $0.10^{* *}$ & 0.80 & 0.84 & 0.04 \\
\hline & Changes on farm & 0.58 & 0.50 & $-0.08^{*}$ & 0.57 & 0.44 & $-0.13^{*}$ \\
\hline & Farm evaluation & 3.57 & 3.23 & $-0.34^{* *}$ & 3.29 & $3 \cdot 39$ & 0.09 \\
\hline
\end{tabular}

suggests that the involvement in OGAs is highly driven by the financial conditions of the household. In terms of land under cultivation, farmers with lesser cultivable land are more inclined towards off-farm income because they find more time to look for offfarm opportunities or they earn too little and are forced to supplement the household income from other means. Specialization in horticultural crops is also highly significant. Many farmers explained that the returns from cherry gardens are relatively higher and that many of them are considering a shift to highvalue crops. Farmer characteristics such as having a spouse on the farm, having a farm heir, the number of younger children, the number of hired workers and the overall satisfaction with the farming activity are linked with farm diversification.

We then identified the determinants of OGAs in GB. The estimated logit models show the results for the factors affecting different categories of OGAs (i.e., farm diversification and off-farm work). Each type of OGA is influenced by different variables. The parameter estimates (Table 3) of the logistic regression specify the direction of the impact and level of significance between the dependent and independent variables, while the marginal effects (Table 4) show the magnitude of the impacts (i.e., per unit change in independent variables leading to the extent of influence on the dependent variables).

Farmer characteristics: Farmers' personal characteristics are found to be one of the major determinants of OGAs and their impact is different in each type of non-farm activity. For example, gender is not relevant in farm diversification while it is positively and significantly related to off-farm work. This, as previously mentioned, can be explained by the male-dominated off-farm job sector. It is considered a cultural norm in Pakistan that the men in the family are mainly assigned financial responsibilities while women in rural areas take up household responsibilities. The probability of involvement in off-farm work increases by $12 \%$ if a farm manager is male. Similar tendencies are reported by Lagerkvist Carl et al. (2007) and Kassie et al. (2017). Similarly, farmer age is significantly 
Table 3 Results from the logit regressions

\begin{tabular}{|c|c|c|c|c|c|}
\hline \multirow{2}{*}{\multicolumn{2}{|c|}{ Variables }} & \multicolumn{2}{|c|}{ Farm diversification } & \multicolumn{2}{|c|}{ Off-farm work } \\
\hline & & Coef. & SE & Coef. & SE \\
\hline \multirow{10}{*}{$\begin{array}{l}\text { Farmer } \\
\text { characteristics }\end{array}$} & Gender & -0.37 & 0.28 & $0.98^{* * *}$ & 0.27 \\
\hline & Age & $0.23^{* *}$ & 0.11 & $-0.44^{* * *}$ & 0.10 \\
\hline & Education & 0.18 & 0.11 & $0.44^{* * *}$ & 0.11 \\
\hline & Experience & 0.04 & 0.10 & 0.12 & 0.10 \\
\hline & Marital status & -0.15 & 0.47 & -0.02 & 0.43 \\
\hline & Number of children (aged $<16$ years) & $0.33^{* * *}$ & 0.11 & 0.01 & 0.10 \\
\hline & Farm heir & $0.74^{* *}$ & 0.37 & -0.21 & 0.32 \\
\hline & Spouse on farm & $0.18^{*}$ & 0.29 & 0.35 & 0.27 \\
\hline & Health status & 0.03 & 0.14 & $0.16^{*}$ & 0.13 \\
\hline & Trainings & 0.07 & 0.06 & $-0.09^{* *}$ & 0.05 \\
\hline \multirow{7}{*}{ Farm size } & Land owned & $0.02^{* *}$ & 0.01 & 0.00 & 0.01 \\
\hline & Land under cultivation & -0.06 & 0.05 & 0.06 & 0.06 \\
\hline & Livestock units & 0.00 & 0.01 & 0.00 & 0.01 \\
\hline & Total workers & $0.15^{* *}$ & 0.06 & $-0.13^{* *}$ & 0.06 \\
\hline & Hired workers & -0.06 & 0.07 & -0.09 & 0.06 \\
\hline & Family workers & $0.80^{* *}$ & 0.39 & 0.36 & 0.31 \\
\hline & Total household members & 0.00 & 0.04 & 0.02 & 0.04 \\
\hline \multirow{3}{*}{ Farm income } & Agricultural income & 0.00 & 0.00 & $-0.01^{* *}$ & 0.00 \\
\hline & Farm income satisfaction & $-4.69^{* * *}$ & 1.24 & 1.65 & 1.04 \\
\hline & Subsidy & $-0.84^{* *}$ & 0.35 & $-0.51^{*}$ & 0.31 \\
\hline \multirow{4}{*}{ Farm location } & Farm altitude & -0.00 & 0.00 & -0.00 & 0.00 \\
\hline & Nearness to a touristic spot & -0.20 & 0.29 & $0.40^{*}$ & 0.28 \\
\hline & Distance from main city $(\mathrm{km})$ & $-0.02^{*}$ & 0.01 & $-0.02^{* *}$ & 0.01 \\
\hline & Distance from main road $(\mathrm{km})$ & 0.04 & 0.05 & 0.06 & 0.07 \\
\hline \multirow{5}{*}{ Others } & Specialist horticulture & $1.80^{* * *}$ & 0.28 & 0.22 & 0.27 \\
\hline & Farm ownership nature & $-0.76^{* *}$ & 0.33 & $-0.63^{*}$ & 0.36 \\
\hline & Changes on farm & $0.34^{* * *}$ & 0.11 & -0.18 & 0.11 \\
\hline & Farm evaluation & $1.07^{* * *}$ & 0.29 & -0.02 & 0.29 \\
\hline & Cons & $3.12^{* * *}$ & 1.26 & $2.39^{* *}$ & 1.07 \\
\hline \multicolumn{2}{|l|}{ Pseudo R² } & 0.26 & & 0.21 & \\
\hline \multicolumn{2}{|l|}{ Prob. $>\chi^{2}$} & 0.40 & & 0.42 & \\
\hline \multicolumn{2}{|l|}{ Observations } & 431 & & 431 & \\
\hline
\end{tabular}

Notes: Significance levels: ${ }^{*} p<0.10,{ }^{* *} p<0.05,{ }^{* * *} p<0.01$

related to both farm diversification and off-farm work. However, older farmers are more likely to be involved in diversification and younger farmers are inclined towards off-farm work. Besides the opportunities in the off-farm market, older farmers have limited ability to work on multiple ventures. Farmers' education is only significantly associated with offfarm work. Farm managers with higher education levels are more ambitious and progressive and they are more capable of finding opportunities in different non-agricultural industries. These findings are plausible as the opportunity cost of farm activities increases with educational qualification and age. The results are consistent with that of other studies (Dries et al. 2011; Liu et al. 2013; Mishra and El-Osta 2016). Furthermore, our results indicate that health is only relevant in the case of off-farm work which is plausible from the fact that most off-farm opportunities are available further away from the farm households making it difficult for aged farmers to access. This finding somehow differs from that of a study in mountainous areas of China which found that the age and health of the farmer have no significant relevance with OGAs (Liu et al. 2013). The farmers' health status is positively linked with off-farm work while agricultural training is negatively associated with it.

Farmer characteristics related to children are particularly important in farm diversification. The higher number of dependent children ( $<16$ years age) is positively linked ( $1 \%$ level of significance) with farm diversification but not significantly related to off-farm work, indicating that increased responsibility tends to push farm managers towards farm diversification. Table 4 shows that an increase in the number of dependent children by 1 leads to a $5 \%$ increase in the probability of setting up a diversification activity. The presence of a farm heir is also positively linked with 
Table 4 Marginal effects for the logit regression estimates

\begin{tabular}{|c|c|c|c|c|c|}
\hline \multirow{2}{*}{ Variables } & & \multicolumn{2}{|c|}{ Farm diversification } & \multicolumn{2}{|c|}{ Off-farm work } \\
\hline & & $\mathrm{dy} / \mathrm{dx}$ & SE & $\mathrm{dy} / \mathrm{dx}$ & SE \\
\hline \multirow{10}{*}{$\begin{array}{l}\text { Farmer } \\
\text { characteristics }\end{array}$} & Gender & -0.04 & 0.04 & $0.12^{* * *}$ & 0.04 \\
\hline & Age & $0.03^{* *}$ & 0.02 & $-0.07^{* * *}$ & 0.01 \\
\hline & Education & 0.03 & 0.02 & $0.07^{* * *}$ & 0.02 \\
\hline & Experience & 0.00 & 0.02 & 0.02 & 0.02 \\
\hline & Marital status & -0.03 & 0.07 & -0.03 & 0.07 \\
\hline & Number of children (aged $<16$ years) & $0.05^{* * *}$ & 0.02 & 0.00 & 0.02 \\
\hline & Farm heir & $0.11^{* *}$ & 0.05 & -0.04 & 0.05 \\
\hline & Spouse on farm & $0.13^{*}$ & 0.06 & 0.04 & 0.05 \\
\hline & Health status & 0.03 & 0.02 & $0.04^{*}$ & 0.02 \\
\hline & Trainings & 0.01 & 0.01 & $-0.02^{* *}$ & 0.01 \\
\hline \multirow{7}{*}{ Farm size } & Land owned & $0.08^{* *}$ & 0.00 & 0.00 & 0.00 \\
\hline & Land under cultivation & -0.01 & 0.01 & 0.01 & 0.01 \\
\hline & Livestock units & 0.00 & 0.00 & 0.00 & 0.00 \\
\hline & Total workers & $0.03^{* *}$ & 0.01 & $-0.02^{* *}$ & 0.02 \\
\hline & Hired workers & -0.02 & 0.01 & -0.04 & 0.02 \\
\hline & Family workers & $0.01^{* *}$ & 0.02 & 0.04 & 0.02 \\
\hline & Total household members & 0.00 & 0.01 & 0.01 & 0.01 \\
\hline \multirow{3}{*}{ Farm income } & Agricultural income & 0.00 & 0.00 & $-0.01^{* *}$ & 0.00 \\
\hline & Farm income satisfaction & $-0.13^{* * *}$ & 0.05 & 0.09 & 0.05 \\
\hline & Subsidy & $-0.16^{* *}$ & 0.04 & $-0.02^{*}$ & 0.05 \\
\hline \multirow{4}{*}{ Farm location } & Farm altitude & -0.00 & 0.00 & -0.00 & 0.00 \\
\hline & Nearness to a touristic spot & -0.01 & 0.04 & $0.12^{*}$ & 0.05 \\
\hline & Distance from main city $(\mathrm{km})$ & $-0.00^{*}$ & 0.00 & $-0.00^{* *}$ & 0.00 \\
\hline & Distance from main road $(\mathrm{km})$ & 0.01 & 0.01 & 0.01 & 0.01 \\
\hline \multirow{4}{*}{ Others } & Specialist horticulture & $0.27^{* * *}$ & 0.04 & 0.01 & 0.04 \\
\hline & Farm ownership nature & $-0.11^{* *}$ & 0.05 & $-0.09^{*}$ & 0.06 \\
\hline & Changes on farm & $0.03^{* * *}$ & 0.04 & -0.04 & 0.04 \\
\hline & Farm evaluation & $0.05^{* * *}$ & 0.02 & -0.02 & 0.02 \\
\hline
\end{tabular}

Notes: Significance levels: ${ }^{*} p<0.10,{ }^{* *} p<0.05,{ }^{* * *} p<0.01$

farm diversification. Its impact on diversification is mainly reflected in that farm managers continue to expand the farm business through setting up diversification activities while nominated farm heirs do not directly contribute to farm decisions and plan to take over farms later in their lives. Nearly twothirds of the farm managers with a nominated farm heir are near the age of retirement or at the age of retirement. Farm managers tend to improve farm productivity and efficiency before it is transferred to a successor. The marginal effects show that the presence of a farm heir increases the probability of farm diversification by $11 \%$. Similarly, the presence of a spouse also positively and significantly increases the likelihood of farm diversification (+13\%).

Hence, overall, personal characteristics reflecting farmers' social capital constitute the most important bundle of variables that are positively linked with farmers' livelihood strategies, i.e., with both farm diversification and off-farm work. According to our results, in particular off-farm work activities in the mountainous region of GB are determined by farmers' personal characteristics that also constitute the basis for the formation of their social capital. This sensitivity of livelihood strategies to social capital in mountain regions has also been found by Fang et al. (2014). Therefore, our first hypothesis is accepted.

Farm size: The size of the landholding is generally negatively associated with off-farm work. However, some of the main diversification activities such as the processing of farm products is done at the larger farms in Pakistan which can be attributed to its positive relationship (5\% level of significance) with diversification. Marginal effects indicate that an increase in landholding by 1 kanal increases the likelihood of farm diversification by $8 \%$. The number of total workers on the farm is significantly ( $5 \%$ level of significance) linked with both farm diversification and off-farm work. However, one individual increase in total workers increases the probability of farm diversification by $3 \%$ and decreases the likelihood of off-farm work by $3 \%$. Furthermore, the involvement of family labor is significantly and positively related to farm diversification, such that the increase in family workers by one unit leads to a $3 \%$ increased probability of farm diversification. 
Farm income: Agricultural income is negatively associated with off-farm work while satisfaction associated with it is negatively related (1\% level of significance) with farm diversification. At the same time, the provision of a subsidy is negatively associated with both types of OGAs. The marginal effects indicate that an increase of 1-thousand Pakistani Rupees in agricultural income would make farmers involvement in off-farm work $1 \%$ less likely. Furthermore, if farmers are satisfied with their agricultural income the likelihood of involvement in farm diversification reduces by $13 \%$. This reflects that the economic conditions are one of the drivers of the non-farm economy in rural mountainous areas and that it pushes farmers to behave in a risk-averse manner. Results from the study by Serra et al. (2004) also indicate that off-farm income is more important to the households experiencing greater volatility in farm income which is true in the context of mountain areas. Similar trends are reported in the agro-pastoral mountainous region of the eastern Tibetan Plateau (Zhang et al. 2008). Lower agricultural income motivates farmers' involvement in off-farm work; however, farm diversification is not significantly linked with it. This is also related to the motives of OGAs; both diversification and off-farm work are found to be driven by economic interests. However, diversification is more linked with farm continuity and sustainability while off-farm work is directly guided by the income situation of the farm households. This finding is in line with other studies (Northcote and Alonso 2011; Vik and McElwee 2011).

Farm location: The geographical position of a farm is expected to have a significant impact on the decision to pursue OGAs. The nearness to a touristic location offers a significant opportunity of earnings from tourism-related services during peak seasons and is positively related (10\% level of significance) to off-farm work. The results show that a farm location near a touristic spot increases the probability of an off-farm activity by $12 \%$. The distance from a main city or town is negatively related to both types of OGAs, as it limits access to the off-farm job market. This result is consistent with the findings of Alasia et al. (2009), Boncinelli et al. (2018) and Phimister et al. (2002) that location-related variables are relevant in the decision whether to pursue OGAs or not.

Other factors: Variables such as farmer evaluations of their farm performance, changes and developments made on the farm, the ownership nature and specialization in horticulture are also among important determinants of OGAs, especially farm diversification. Farm managers who work on rented landholdings and smaller farms are less likely to involve in diversification activities. Boncinelli et al. (2018) found similar results. Higher scores in the evaluation of last year's progress on the farm are also positively and significantly linked with diversification. Lastly, the specialization in horticultural crops, particularly in the context of the study area is found to be highly relevant in the pursuit of farm diversification. The marginal effects show that if a farm is specialized in horticulture, then the likelihood of its involvement in diversification activities such as the processing and direct consumer sales of its horticultural products increases by $27 \%$. This can be attributed to the increasing trend of the commercialization of high-value crops in the region.

Hence, overall, our results confirm that farmspecific variables such as size, agricultural income, location and other characteristics significantly affect the decision to pursue OGAs. These variables are particularly relevant for explaining farm diversification activities (10 out of 18 variables are significant as compared to 6 out of 18 variables for off-farm work). Moreover, the variables 'specialist horticulture', 'subsidy' and 'farm income satisfaction' display the highest effect sizes (marginal effects) among all the investigated variables for explaining farm diversification activities. This confirms our second hypothesis. Overall, we find that in GB social capital-related farmer characteristics are somewhat more important for explaining the engagement in offfarm work while farm characteristics are more important for explaining farm diversification activities.

\section{Conclusion and Policy Recommendations}

This study is based in five rural mountainous regions of Gilgit-Baltistan, Pakistan, which have their individual geopolitical and agro-economic importance. During the last few decades, the trend of commercialization in agriculture and more recently the surge of tourism has affected the structure of agriculture and the livelihoods of the rural communities. We examined the status and trends of these livelihood strategies (called OGAs) and the factors influencing farmers to engage in these 
activities. Based on the analysis, we found that different types of activities outside conventional agriculture are prevalent in the region. Many farmers use non-agricultural income channels because of financial and economic needs or decreasing returns from on-farm labor or merely as efficient utilization of surplus time and labor. For some farmers, OGAs are a means to sustain and stay in the farming profession. With the pressures from the current economic downturn, climatic and geographical constraints and unemployment, farmers showed concerns over livelihood conditions, emphasizing the need for government interventions. Furthermore, significant differences exist between farm managers with and without different types of OGAs (i.e., farm diversification and off-farm work). In GB, farmers with diversification are relatively older, have more younger dependents, more hired workers, a spouse working on the farm, are specialized in horticulture etc. On the contrary, farmers involved in off-farm activities are relatively younger, more educated, have lesser farm income, have lesser land under cultivation, etc. Our econometric analysis provided useful insights into the drivers of the non-farm economy. It showed that farmer characteristics mainly determine off-farm work activities while farm (and other) characteristics mostly explain farm diversification.

From a policy perspective, our findings have important implications. Depending on the actual aim of the overall regional rural development policy, priorities may have to be specified. While the concept of agricultural multifunctionality may help to stabilize farm numbers in rural areas and slow land flight and rural-urban migration, a policy that does not specifically target and support agricultural production activities may in the long run create wider food security and regional food supply problems. However, this is not a call for "overemphasizing" high levels of local food self-sufficiency (Spies 2018) but to help ensuring adequate food production resources and capabilities contributing to sustainably and healthily feed the region as well as a world population of almost 10 billion people in 2050.

For the strengthening of the non-farm rural economy, our results indicate that in GB policy measures supporting the building of farmers' social capital such as education and training especially at a younger age strongly impact the likelihood of off-farm work. Therefore, investments in building the social capital of these rural communities are suggested.
For policies aiming at the promotion of farm diversification activities, the government needs to improve the local farm structure and farm income situation. For this purpose, instead of income subsidies, farm subsidies directed at supporting and stabilizing diversified farms will be helpful in the long run. Moreover, the promotion of technological innovation in the farming sector can help to retain the younger segments of the rural labor force on the farms. Wider support frameworks for diversification would also need to consider farmer skills development, cooperation and market-chain integration measures, as well as integrated rural development aspects, considering the specificities of mountain locations and products.

Finally, through land rehabilitation programs and land development schemes, farming opportunities could be enhanced in the region. This will all help to improve rural livelihoods while securing agricultural and particularly food supply in the mountainous regions of GB.

\section{Acknowledgements}

We thank Dr. Fazal Rehman at the Directorate of Agriculture Research Gilgit-Baltistan, Mr. Mahmood Asghar at the Department of Agriculture Extension Gilgit-Baltistan, Government of Gilgit-Baltistan, Pakistan for their support in questionnaire design and data collection. The valuable research support by Dr. Valérie Bossi Fedrigotti, previously at the Faculty of Science and Technology, Free University of BozenBolzano, South Tyrol, Italy during the questionnaire design and data collection phases of this study is recognized. We also thank the regional agricultural officers for their guidance and assistance throughout the survey. This research has been funded by the scholarship offered by the Free University of BozenBolzano.

Open Access This article is distributed under the terms of the Creative Commons Attribution 4.0 International License

(http://creativecommons.org/licenses/by/4.o/), which permits unrestricted use, distribution, and reproduction in any medium, provided you give appropriate credit to the original author(s) and the source, provide a link to the Creative Commons license, and indicate if changes were made. 


\section{References}

AKRSP (2017) Horizons of CPEC in Gilgit Baltistan: A prospective study.

http://akrsp.org.pk/wp-content/uploads/2018/o9/Horizonsof-CPEC-in-Gilgit-Baltistan.pdf (Accessed on 4 June 2021)

Alasia A, Weersink A, Bollman RD, Cranfield J (2009) Off-farm labour decision of Canadian farm operators: Urbanization effects and rural labour market linkages. J Rural Stud 25(1): 12-24. https://doi.org/10.1016/j.jrurstud.2008.04.002

Amjad A, Shafiqa A, Sophia FD (2017) Social and family capital and youth career intension: A case study in Pakistan. Cog Bus \& Manag 4:1. https://doi.org/10.1080/23311975.2017.1362838

Andersson H, Ramamurtie S, Ramaswami B (2003) Labor income and risky investments: can part-time farmers compete? J Econ Behav \& Org 50(4): 477-493. https://doi.org/10.1016/So167-2681(02)ooo38-o

Anwar S, Khan FA, Rahman A (2019) Impact of karakoram highway on land use and agricultural development of GilgitBaltistan, Pakistan. Sarhad J Agr 35(2): 417-431. http://dx.doi.org/10.17582/journal.sja/2019/35.2.417.431

Atamanov A, Van Den Berg M (2012) Rural nonfarm activities in Central Asia: A regional analysis of magnitude, structure, evolution and drivers in the Kyrgyz Republic. Euro-Asia Stud 64(2): 349-368.

https://doi.org/10.108o/o9668136.2011.642581

Awokuse TO, Xie R (2015) Does Agriculture really matter for economic growth in developing countries? Can J Agr Econ 63(1): 77-99.

https://doi.org/10.1111/cjag.12038

Barbieri C, Mahoney E (2009) Why is diversification an attractive farm adjustment strategy? Insights from Texas Farmers and Ranchers. J Rural Stud 25: 58-66. https://doi.org/10.1016/j.jrurstud.2008.06.001

Barnes AP, Hansson H, Manevska-Tasevska G, et al. (2014) The Influence of diversification on short-term and long-term viability in the Scottish and Swedish agricultural sector. 2014 International Congress, August 26-29, 2014, Ljubljana, Slovenia.

Bateman D, Ray C (1994) Farm pluriactivity and rural policy: Some evidence from Wales. J Rural Stud 10(1): 1-13. https://doi.org/10.1016/0743-0167(94)90002-7

Benz A (2016) Framing modernization interventions: Reassessing the role of migration and translocality in sustainable mountain development in Gilgit-Baltistan, Pakistan. Mt Res Dev 36(2):141-152 (2016). https://doi.org/10.1659/MRD-JOURNAL-D-15-00055.1

Bhasin V (2011) Pastoralists of Himalayas. J Hum Eco 33(3): 147-177.

Boncinelli F, Bartolini F, Casini L (2018) Structural factors of labour allocation for farm diversification activities. Land Use Policy 71: 204-212. https://doi.org/10.1016/j.landusepol.2017.11.058

Brosig S, Glauben T, Herzfeld T, Wang X (2009) Persistence of full- and part-time farming in Southern China. China Econ Rev 20(2): 360-371. https://doi.org/10.1016/j.chieco.2008.10.005

Chase $J$ (2010) The place of pluriactivity in Brazil's agrarian reform institutions. J Rural Stud 26(1): 85-93. https://doi.org/10.1016/j.jrurstud.2009.07.001

Commission E (2008) Other Gainful Activities : Pluriactivity and Farm Diversification in EU-27 AGRI G2.

da Silva VR, da Silva MM, Pereira MCD (2015) Pluriactivity and sustainability in rural communities of semiarid Northeast. Desenvolvimento E Meio Ambiente 35: 349-366.

Damianos D, Skuras D (1996) Farm business and the development of alternative farm enterprises: An empirical analysis in Greece. J Rural Stud 12(3): 273-283. https://doi.org/10.1016/0743-0167(96)00017-4
Darnhofer I (2010) Strategies of family farms to strengthen their resilience. Envir Policy Gov 20(4): 212-222.

https://doi.org/10.1002/eet.547

Dedehouanou SFA, McPeak J (2020) Diversify more or less? Household income generation strategies and food security in rural Nigeria. J Dev Stud 56(3): 560-577.

https://doi.org/10.1080/00220388.2019.1585814

Dinar H, Chaudhry W, Chaudhry AG, et al. (2015) Transformation and retention: A case study of Hunzukutz in Islamabad. Sci Intl Lhr 27(1): 741-743.

Dries L, Pascucci S, Gardebroek C (2011) Pluriactivity in Italian Agriculture: Are farmers using interlinked strategies? Euro Assoc Agr Econ.

https://core.ac.uk/download/pdf/29232363.pdf

Fang Y, Fan J, Shen M, et al. (2014) Sensitivity of livelihood strategy to livelihood capital in mountain areas: Empirical analysis based on different settlements in the upperreaches of the Minjiang River, China. Ecol Indic 38: 225-235 https://doi.org/10.1016/j.ecolind.2013.11.007

Fischer C (2019) Agriculture and tourism sector linkages: Global relevance and local evidence for the case of South Tyrol. Open Agr 4(1): 544-553. https://doi.org/10.1515/opag-2019-0053

Freyens B, Mann S (2016) Part-time farming and resellience: Evidence from Australia. 56th Annual Conference, Bonn, Germany, September 28-30, 2016 244863, German Association of Agricultural Economists (GEWISOLA).

Fuller AM (1990) From part-time farming to pluriactivity: a decade of change in Rural Europe. J Rural Stud 6(4): 361-373. https://doi.org/10.1016/0743-0167(90)90049-E

Gasson and Ruth (1986) Part time farming strategy for survival? Socio Rural 26(3-4): 364-376.

Gautam Y, Andersen P (2016) Rural livelihood diversification and household well-being: Insights from Humla, Nepal. J Rural Stud 44: 239-249. https://doi.org/10.1016/j.jrurstud.2016.02.001

Gómez-Limón JA, Vera-Toscano E, Garrido-Fernández FE (2014) Farmers' Contribution to Social Capital. Rural Sociol 79: $380-410$. https://doi.org/10.1111/ruso.12034

Guttman JM, Haruvi N (1986) Cooperation and part-time farming in the Israeli Moshav. Amer J Agr Econ 68(1): 77-87. https://doi.org/10.2307/1241651

Haggblade S, Hazell PB, Reardon T (eds.) (2007) Transforming the Rural Nonfarm Economy: Opportunities and Threats in the Developing World. International Food Policy Research Institute. Johns Hopkins University Press.

Hansson H, Ferguson R, Olofsson C, et al. (2013) Farmers' motives for diversifying their farm business - The influence of family. J Rural Stud 32: 240-250.

https://doi.org/10.1016/j.jrurstud.2013.07.002

Hoermann B, Kollmair M (2009) Labour Migration and Remittances in the Hindu Kush-Himalayan Region. International Centre for Integrated Mountain Kathmandu.

Holland D, Carvalho J (1985) The changing mode of production in American agriculture: emerging conflicts in agriculture's role in the reproduction of advanced capitalism. Rev Rad Polit Econ 17(4): 1-27.

https://doi.org/10.1177/048661348501700402

Hussain A, Fisher D, Espiner S (2017) Transport infrastructure and social inclusion: A case study of tourism in the region of Gilgit-Baltistan. Soc Incl 5(4): 196-208.

https://doi.org/10.17645/si.v5i4.1084

Hussain A, Rasul G, Mahapatra B, et al. (2016) Household food security in the face of climate change in the Hindu-Kush Himalayan region. Food Sc 8(5): 921-937 https://doi.org/10.1007/s12571-016-0607-5

IFAD (2015) Economic Transformation Initiative GilgitBaltistan Programme Design Report. Lahore: Asia and the 
Pacific Division IFAD.

Ilbery BW, Bowler IR (1993) The farm diversification grant scheme: Adoption and nonadoption in England and Wales. Environment and Planning C: Gov Policy 11(2): 161-170. https://doi.org/10.1068/c110161

Imran S, Alam K, Beaumont N (2014) Environmental orientations and environmental behaviour: Perceptions of protected area tourism stakeholders. Tour Manag 40, 290299. https://doi.org/10.1016/j.tourman.2013.07.003

Iqbal M, Ping Q, Ahmed U, et al. (2015). Determinants of Offfarm Activity Participation among Cotton Farmers in Punjab, Pakistan. Intl J Manag Account Econ 2 (7): 707-718.

Israr M, Khan H (2010) An analysis of livelihood sources in hilly areas of northern Pakistan. Sarhad J Agriculture 26(4): 665672.

Kassie GW, Kim S, Fellizar FP (2017) Determinant factors of livelihood diversification: Evidence from Ethiopia. Cog Soc Sci 3(1): 1369490 https://doi.org/10.1080/23311886.2017.1369490

Khan MZ, Khan B, Awan S, et al. (2013) High-altitude rangelands and their interfaces in Gilgit-Baltistan, Pakistan: current status and management strategies. High-Altitude Rangelands and their Interfaces in the Hindu Kush Himalayas, 66.

Kimhi A (2000) Is part-time farming really a step in the way out of agricultural? Amer J Agri Econ 82(1): 38-48. https://doi.org/10.1111/0002-9092.00004

Kimhi A (2010) Does rural household income depend on neighboring communities? Evidence from Israel.

https://doi.org/10.22004/ag.econ.93134

Kinsella J, Wilson S, de Jong F, et al. (2000) Pluriactivity as a livelihood strategy in Irish farm households and its role in rural development. Soc Rural 40(4): 481-496.

https://doi.org/10.1111/1467-9523.00162

Kumar K (1989) Conducting key informant interviews in developing countries. Agency for International Development Washington DC.

Lagerkvist Carl J, Larsen K, Olson KD (2007) Off-farm income and farm capital accumulation: a farm-level analysis. Agr Financ Rev 67(2): 241-257. https://doi.org/10.1108/00214660780001207

Lakner S, Kirchweger S, Hoop D, et al. (2018) The effects of diversification activities on the technical efficiency of organic farms in Switzerland, Austria, and Southern Germany. Sustainability 10(4): 1304 . https://doi.org/10.3390/su10041304

Liu SQ, Zhang HQ, Xie FT, et al. (2013) Current situation and influencing factors of pluriactivity in mountainous and hilly rural areas of Sichuan province, China. J Mt Sci 10(3): 445454.

https://doi.org/10.1007/s11629-013-2415-6

Lowder S, Skoet J, Raney T (2016) The number, size, and distribution of farms, smallholder farms, and family farms worldwide. World Dev 87: 16-29.

https://doi.org/10.1016/j.worlddev.2015.10.041

López-i-Gelats F, Milán MJ, Bartolomé J (2011) Is farming enough in mountain areas? Farm diversification in the Pyrenees. Land Use Policy 28(4): 783-791.

https://doi.org/10.1016/j.landusepol.2011.01.005

Lopez-i-Gelats F, MG Rivera-Ferre C, Madruga-Andreu C, et al. (2015) Is multifunctionality the future of mountain pastoralism? Lessons from the management of semi-natural grasslands in the Pyrenees. Spanish J Agr Res 13(4). https://doi.org/10.5424/sjar/2015134-6960

Lund PJ (1991) Part-time farming - A note on definitions. J Agr Econ 42(2): 196-199.

https://doi.org/10.1111/j.1477-9552.1991.tboo348.x

Maye D, Ilbery B, Watts D (2009) Farm diversification, tenancy and CAP reform: Results from a survey of tenant farmers in England. J Rural Stud 25(3): 333-342.

https://doi.org/10.1016/j.jrurstud.2009.03.003

McNally S (2001) Farm diversification in England and Wales - what can we learn from the farm business survey? J Rural Stud 17(2): 247-257.

https://doi.org/10.1016/So743-0167(0o)0o050-4

McNally S (2002) Are 'Other Gainful Activities' on farms good for the environment? J Env Manag 66(1): 57-65. https://doi.org/10.1006/jema.2002.0576

McNamara KT, Weiss C (2005) Farm Household Income and On- and Off-Farm Diversification. J Agr Appl Econ 37(1): 3748. https://doi.org/10.1017/S1074070800007082

Meert H, Van Huylenbroeck G, Vernimmen T, et al. (2005) Farm household survival strategies and diversification on marginal farms. J Rural Stud 21(1): 81-97. https://doi.org/10.1016/j.jrurstud.2004.08.007

Mishra AK, El-Osta HS (2016) Determinants of decisions to enter the U.S. farming sector. J Agr Appl Econ 48(1): 73-98. https://doi.org/10.1017/aae.2015.25

Mishra AK, Fannin JM, Joo H (2014) Off-farm work, intensity of government payments, and farm exits: Evidence from a national survey in the United States. Canadian J Agr Econ 62(2): 283-306.

https://doi.org/10.1111/cjag.12027

Monge M, Hartwich F, Halgin D (2008) How Change Agents and Social Capital Influence the Adoption of Innovations among Small Farmers. Evidence from Social Networks in Rural Bolivia. Discussion Paper 00761. International Food and Policy Research Institute (IFPRI): Washington.

Naudiyal N, Arunachalam K, Kumar U (2019) The future of mountain agriculture amidst continual farm-exit, livelihood diversification and outmigration in the Central Himalayan villages. J Mt Sci 16(4): 755-768. https://doi.org/10.1007/s11629-018-5160-6

Niemelä T, Häkkinen R (2014) The role of pluriactivity for continuity and survival in family farm firms. J Ent Manag Innov 10(4): 7-44.

Northcote J, Alonso AD (2011) Factors underlying farm diversification: the case of Western Australia's olive farmers. Agr Human Values 28(2): 237-246.

https://doi.org/10.1007/s10460-010-9274-x

OECD (2009) The Role of Agriculture and Farm Household Diversification in the Rural Economy: Evidence and Initial Policy Implications. TAD/CA/APM/WP(2009)1/FINAL

Paudel KP, Wang Y (2002) Part Time Farming, Farm Productivity, and Farm Income: Evidence from the Southeast US.

https://core.ac.uk/download/pdf/7001614.pdf

Pfeffer MJ (1989) Part-time farming and the stability of family farms in the Federal Republic of Germany 1. Euro Rev Agr Econ 16(4): 425-444.

https://doi.org/10.1093/erae/16.4.425

Phimister E, Vera-Toscano E, Weersink A (2002) Female participation and labor market attachment in rural Canada. Amer J Agr Econ 84(1): 210-221.

https://doi.org/10.1111/1467-8276.00253

Phongsavan P, Chey T, Bauman A, et al. (2006) Social capital, socio-economic status and psychological distress among Australian adults. Soc Sci \& Med 63(10):2546-61. https://doi.org/10.1016/j.socscimed.2006.06.021

Pietola K, Väre M, Lansink AO (2003) Timing and type of exit from farming: farmers' early retirement programmes in Finland. Euro Rev of Agr Econ 30(1): 99-116. https://doi.org/10.1093/erae/30.1.99

Puri LUV (2009) Pakistan's Northern Areas: Time for a Reality Check. Econ Polit Weekly 44(39): 13-15.

Qureshi MA, Yi C, Xu X, et al. (2017) Glacier status during the period 1973-2014 in the Hunza Basin, Western Karakoram. Quater Intl 444: 125-136. https://doi.org/10.1016/j.quaint.2016.08.029

Rasul G (2010) The Role of the Himalayan mountain systems in food security and agricultural sustainability in South Asia. Intl J Rural Manag 6(1): 95-116. https://doi.org/10.1177\%2Fo97300521100600105 
Rasul G, Hussain A (2015) Sustainable food security in the mountains of Pakistan: Towards a policy framework. Eco Food Nutr 54(6): 625-643.

https://doi.org/10.1080/03670244.2015.1052426

Rivera M, Knickel K, María Díaz-Puente J, et al. (2019) The role of social capital in agricultural and rural development: Lessons learnt from case studies in seven countries. Soc Ruralis 59: 66-91.

https://doi.org/10.1111/soru.12218

Rivera M, Knickel K, I.de los Rios, et al. (2018) Rethinking the connections between agricultural change and rural prosperity: A discussion of insights derived from case studies in seven countries. J Rural Stud 59:242-251.

https://doi.org/10.1016/j.jrurstud.2017.07.006

Robson N, Gasson R, Hill B (1987) Part time farming Implications for family income. J Agr Econ 38(2): 167-192. https://doi.org/10.1111/j.1477-9552.1987.tbo1039.x

Rockström J, Williams J, Daily G, et al. (2017) Sustainable intensification of agriculture for human prosperity and global sustainability. Ambio 46(1): 4-17.

https://doi.org/10.1007/s13280-016-0793-6

Rosa P, Kodithuwakku S, Balunywa W (2008) Entrepreneurial motivation in developing countries: What does 'necessity' and 'opportunity' entrepreneurship really mean? Front Ent Res26:1-14. https://dx.doi.org/10.2139/ssrn.1310913

Salvioni C, Henke R, Vanni F (2020) The impact of nonagricultural diversification on financial performance: Evidence from family farms in Italy. Sustainability 12(2): 486. https://doi.org/10.3390/su12020486

Sano S, Tada S, Yamamoto M (2015) Method of household surveys and characteristics of surveyed households: Comparison regarding household composition, annual income and educational attainment. Publ Policy Rev 11(4): 505-529.

Sati VP (2005) Systems of agriculture farming in the Uttranchal Himalaya, India. J Mt Sci 2(1): 76-85.

https://doi.org/10.1007/s11629-005-0076-3

Schmitt M (2009) An inter-generational comparison of pluriactivity from a gender perspective. OGA Jahrbuch - J Aust Soc Agr Econ 18(2): 119-133.

Serra T, Goodwin Barry K, Featherstone Allen M (2004) Determinants of investments in non-farm assets by farm households. Agr Finan Rev 64(1): 17-32.

https://doi.org/10.1108/00215100480001151

Serra T, Goodwin BK, Featherstone AM (2005) Agricultural policy reform and off-farm labour decisions. J Agr Econ 56(2): 271-285. https://doi.org/10.1111/j.1477-9552.2005.00004.x

Sharpley R, Vass A (2006) Tourism, farming and diversification: An attitudinal study. Tour Manag 27(5): 1040-1052. https://doi.org/10.1016/j.tourman.2005.10.025

Spies M (2018) Changing food systems and their resilience in the Karakoram mountains of northern Pakistan: A case study of Nagar. Mt Res Dev 38(4): 299-309. https://doi.org/10.1659/MRD-JOURNAL-D-18-00013.1

Stadelbauer J (2020) Hunza Matters: Bordering and Ordering Between Ancient and New Silk Roads. By Hermann Kreutzmann. Mt Res Dev 40(3):M1-M2 (2020). https://doi.org/10.1659/mrd.mm254.1

Su W, Eriksson T, Zhang L, et al. (2016). Off-farm employment and time allocation in on-farm work in rural China from gender perspective. China Econ Rev 41: 34-45. https://doi.org/10.1016/j.chieco.2016.08.006

Tocco B, Davidova S, Bailey A (2016) Part-Time Farming in Italy: Does Farm Size Really Matter? 9oth Annual Conference, April 4-6, 2016, Warwick University, Coventry, UK.

Vandermeulen V, Verspecht A, Van Huylenbroeck G, et al. (2006) The importance of the institutional environment on multifunctional farming systems in the peri-urban area of Brussels. Land Use Policy 23(4): 486-501. https://doi.org/10.1016/j.landusepol.2005.06.002

Vik J, McElwee G (2011) Diversification and the entrepreneurial motivations of farmers in Norway. J Small Bus Manag 49(3): 390-410.

https://doi.org/10.1111/j.1540-627X.2011.00327.x

Weiß ML, Hoffmann C, Streifeneder T (2016) Cooperation models and pluri-activity to exhaust value-added potentials in mountain regions. In: Koulov B \& Zhelezov G (eds.), Sustainable Mountain Regions: Challenges and Perspectives in Southeastern Europe. Cham: Springer International Publishing. pp 17-31. https://doi.org/10.1007/978-3-319-27905-3_2

Zabawa R (1987) Macro-micro linkages and structural transformation: The move from full-time to part-time farming in a North Florida agricultural community. Amer Anthropol 89(2): 366-382. https://doi.org/10.1525/aa.1987.89.2.02aooo60

Zhang L, Zhang Y, Yan J, et al. (2008) Livelihood diversification and cropland use pattern in agro-pastoral mountainous region of eastern Tibetan Plateau. J Geogr Sci 18(4): 499-509. https://doi.org/10.1007/s11442-008-0499-1 